самим роблять процес навчання більш ефективним. Економія часу, необхідного для вивчення конкретного матеріалу, в середньому становить 30\%, а набуті знання зберігаються в пам’яті значно довше.

Під час використання на уроці мультимедійних технологій структура уроку принципово не змінюється. У ньому, як і раніше, зберігаються всі основні етапи, зміняться, можливо, тільки їх тимчасові характеристики. Необхідно відзначити, що етап мотивації в даному випадку збільшується і несе пізнавальне навантаження. Це необхідна умова успішності навчання, так як без інтересу до поповнення знань, яких бракує, без уяви і емоцій немислима творча діяльність учнів.

Підсумовуючи сказане, можна зробити висновок, що у процесі інтеракції учнів засобами профільного навчання створюються ефективні умови для комплексного формування життєвої компетентності випускників загальноосвітніх шкіл-інтернатів.

\title{
Література
}

1. Бібік Н.М. Компетентність у навчанні / Н.М. Бібік // Енциклопедія освіти: АПН України; гол. ред. В.Г. Кремень. - К.: Юрінком Інтер, 2008. - С. 408-409.

2. Срмаков І.Г. Формування життєвої компетентності учнів шкіл-інтернатів у контексті комплексної реабілітації: орієнтири до прогностичного експерименту/ І.Г. Єрмаков, Г. М. Несен // Реабілітаційна педагогіка на рубежі XXI століття : [наук.-метод. зб.] у 2-х частинах; ред. рада: В.М. Доній, Г.М. Несен, І.Г. Срмаков та ін. - К. : ІЗМН, 1998. - Ч.2. - С. 113-21.

3. Коберник О.М. Урок трудового навчання в умовах проектно-технологічної системи / О.М.Коберник // Трудова підготовка в закладах освіти. - 2006. - №1. - С.2-5.

4. Освітні технології : [навч.-метод.посіб.] / О.М.Пєхота, А.З.Кіктенко та ін. - К. : A.C.K., 2001. - $256 \mathrm{c}$.

5. Ягупов В.В.Професійна компетентність випускників системи професійнотехнічної освіти / В.В. Ягупов // Система роботи ПТНЗ з формування професійно мобільного кваліфікованого робітника. Матеріали Всеукраїнської науково-практичної конференції (м. Кривий Ріг, 23-24 листопада 2011 р.). - Кривий Ріг: Ін-т ПТО НАМН України, 2011. - С.9-11.

Стаття надійшла до редакції 30.05.2012 p.

УДК 371.134

I. С. Вдовенко, кандидат пед. наук, доиент, Чернігівський наџіональний педагогічний університет імені Т.Г. Шевченка

\section{ЗАСТОСУВАННЯ ЗМАГАЛЬНИХ ІНФОРМАЦІЙНИХ ТЕХНОЛОГІЙ У НАВЧАЛЬНОМУ ПРОЦЕСІ ПРОФЕСІЙНО-ТЕХНІЧНИХ НАВЧАЛЬНИХ ЗАКЛАДІВ}

Вдовенко I. С. Застосування змагальних інформаиійних технологій у навчальному проиесі професійно-технічних навчальних закладів.

У иій статті розглянуто застосування новітніх інформаційний технологій у навчальному процесі професійно-технічних навчальних закладів.

Ключові слова: змагальні інформачійні технологї̈, навчальний прочес, професійнотехнічні навчальні заклади. 
Вдовенко И. С. Применение соревновательный информационных технологий в учебном процессе профессионально-технических учебных заведений.

В этой статье рассмотрено применение новейших информационных технологий в учебном прочессе профессионально-технических учебных заведений.

Ключевые слова: соревновательные информационные технологии, учебный процесс, профессионально-технические учебные заведения. institutions.

Vdovenko I. The usage of emulative information technology in educational process in vocational

The thesis deals with usage of newest information technology in educational process in vocational institutions.

Key words: emulative information technology, educational process, vocational institutions.

Актуальність дослідження. Розвитку змагальності та іiі впливу на активізацію процесу засвоєння знань впливає знання, уміння та готовність до застосування інформаційних технологій.

Застосуванню при організації ЗІТ сприятиме зростання кількості навчальних закладів забезпечених комп'ютерною технікою і відповідно рівень комп'ютерної грамотності. На часі ставиться завдання до застосування інформаційних технологій під час викладання всіх без виключення навчальних курсів і відповідно оволодіння необхідними методами професорсько-викладацького складу.

Інформаційні технології надають можливість здійснювати навчання, а відповідно і змагання дистанційно. Важливим питанням $є$ розроблення програмного забезпечення до застосування комп'ютерних технологій у навчальному процесі.

Постановка питання щодо розширення застосування інформаційних технологій в навчально-виховному процесі особливо актуальне при оцінюванні знань, що безпосередньо позитивно впливатиме на розвиток змагальності, зокрема в частині об'єктивності визначення показників засвоєння знань учнів.

Аналіз останніх досліджень. Інформатизація освіти, яка поширюється швидкими темпами надає такі можливості в практичному вимірі у всіх ланках навчання i $\epsilon$ достатньо дослідженою науковцями: В. Биков, О. Борлак, А. Верлань, В. Сидоренко, О. Торубара.

Мета статті - проаналізувати застосування новітніх інформаційний технологій в змагальному процесі у професійно-технічних навчальних закладах.

Виклад основного матеріалу. Для підготовки майбутніх робітників будьяких робітничих спеціальностей в професійно-технічному освітньому середовищі потрібно створити спеціальні умови для професійного розвитку учнів. Для цього в ПТНЗ застосовується методи змагальності і тому для впровадження цих методів застосовуються інформаційно-комунікаційні технології.

Організації змагання $\mathrm{i}$ рейтингового оцінювання знань сприяє застосування такої технології як облік індивідуальних особливостей учнів, а також навчальних груп. Оскільки це дозволить ставити в навчальному процесі адекватні потребам та можливостям завдання та ранжувати їх за здібностями учасників [4]. 
Для цього необхідно створювати групи розробників програмного продукту та впроваджувати нові елементи змісту навчання.

Типи програм для організації змагання можна класифікувати на:

- Тренувальні. Образно їх можна назвати програмами для змагання 3 самим собою, тобто для порівняння знань після їх засвоєння, повторення та самостійної роботи у певному часовому проміжку порівняно з попередніми періодами. Вони також сприяють усуненню помилок та недоліків у навчанні.

- Контрольні. Вони складаються задля контролю з боку викладача за рівнем засвоєння знань і порівняння знань двох або декількох учнів задля економії часу в подальшому встановленні істинних оцінок та рейтингів. Тобто, ще до остаточних оцінок формується уявлення про рівень засвоєння знань.

- Творчі. Складаються 3 ускладнених завдань і опираються на виявлення умінь моделювати ситуації, процеси, явища. Вони сприятимуть відбору учнів до змагань 3 аналітики, участі в наукових конкурсах, змаганнях знавців, олімпіадах з того, чи іншого предмету.

- Демонстраційні. Програми застосовуються задля демонстрації переваг змагання, його суті та формування зацікавленості брати в ньому участь. Вони мають бути насичені конкретикою, прикладами, носити аудіовізуальний ряд рекламного спрямування.

- Довідкові програми є доповненням для кожного попереднього виду програм або окремими насиченими статистичними, ілюстративними, довідковими матеріалами, що однаковою мірою сприятимуть усім учасникам змагального процесу, які вважатимуть необхідним з ними ознайомитися [2].

Необхідно розробляти методику використання екранного і звукового супроводу та аудіовізуальної допомоги, яка урізноманітнюватиме змагання та сприятиме ефективності як засвоєння матеріалу, так і результатів змагання.

Нині розробляється та широко застосовується методологія щодо запровадження в змаганні дистанційних технологій із застосуванням теоретичних розробок і практичного досвіду функціонування IT в інших сферах діяльності, які дозволять організовувати змагання не лише на рівні класу, групи, а й міжшкільному, міжвузівському, територіальному, регіональному, національному та міждержавному рівні.

Комп'ютерно-комунікаційні технології дозволяють візуально спостерігати за змаганням, організацією оцінювання, яке постійно урізноманітнюється.

Електронні технології дозволяють вивчати особисті характеристики учасників, знайомити з умовами змагання без безпосередньої їх присутності та встановлювати критерії відбору до тих або інших змагань.

Застосування різноманітних технологій у змаганні удосконалює та демократизує його проведення $\mathrm{i}$ сам процес навчання на засадах рівноправної співпраці педагогів і учнів.

Як приклад, можна назвати такі види змагання як ділові ігри під час проведення практичних та семінарських занять. Те що інформаційні технології в змаганні не набули широкого застосування пояснюється такими причинами: 
- по-перше, змагання поки що не є системним чинником активізації навчального процесу;

- по-друге, недостатня кількість прикладних програм, орієнтованих на забезпечення змагального процесу і обробку інформації;

- по-третє, неготовністю педагогічних кадрів до їх застосування як психологічно, так і з професійної точки зору.

Навіть мають місце та обгрунтовуються погляди, що застосування змагальних методів лише ускладнює навчальний процес [6].

Важливим питанням $\epsilon$ моделювання змагальних завдань i всього процесу із застосуванням IT. Складання сценаріїв та програм має передбачати особливості навчального курсу, досвід учнів, теоретичну i практичну підготовку викладачів, уміння працювати 3 програмними засобами, враховувати види змагання (навчальні, тренувальні, практичні, теоретичні), цілі, зміст і способи реалізації, конкретні етапи, дії та результати.

За формування змагальних завдань урахуванню підлягає різна наявна ступінь засвоєння знань - від рівня розпізнавання понять та категорій, уміння їх відтворювати та засвоєння на репродуктивному і творчому рівнях.

Вимоги до педагога зростають 3 таких позицій:

1. Доскональне знання курсу, теми, з якої проводиться змагання.

2. Уміння враховувати індивідуальні особливості учнів.

3. Знання IT як викладачем, так і учнями.

4. Уміння складати програми, тести, завдання.

5. Уміння оцінити змагання засобами IT.

6. Уміння за підсумками зробити висновки та внести корективи до навчального процесу.

7. Забезпечувати наступність, послідовність та нарощування складності завдань.

Оскільки систематизація змагальності, запровадження іiі форм і методів на всіх рівнях навчально-виховного процесу $є$ завданням часу, чинником сприяння конкурентоздатності національної освіти в цілому та фахівців, яких вона готує, зокрема то й вимагає використання і впровадження новітніх інформаційних технологій.

Це дозволить підвищити ефективність навчального процесу, реалізувати методи розвивального навчання, вдосконалити прийоми педагогічної діяльності, управління освітою, наблизити їі до умов ринкового середовища та потреб зайнятості населення [5].

Використання змагальних інформаційних технологій (3IT) в навчально-виховному процесі розширює можливості для засвоєння знань, урізноманітнює та викликає інтерес до навчання, сприяє адаптації до реалій життя, наближає до конкурентних умов, які будуть в професійній діяльності.

Отже, впровадження засад змагальності на основі сучасних технологій необхідне для формування творчої особистості, озброєної досвідом практичних дій, здатної змінювати характер своєї діяльності від репродуктивно-виробничого до творчо-усвідомленого. 
Успіх у професійній діяльності і конкурентоспроможність забезпечить застосування інформаційно-технічних засобів у навчальному процесі насамперед 3 поліпшення викладання предметів професійно-технічного циклу.

Поки що впровадження комп'ютерів у вивчення таких дисциплін не $\epsilon$ системним явищем i тому не дуже впливає на процес поліпшення професійної підготовки.

Однак змагальність 3 цих предметів, де найлегше застосувати комп'ютерні технології практично не застосовується. Хоча можливими змагальними завданнями могло б бути виконання технологічних завдань на швидкість та точність, а також застосування нових комп'ютерних технологій щодо закріплення знань, умінь і навичок, забезпечення зв'язку між різними предметами спеціальності, фах з якої здобуває учень.

У змагальних програмах, зокрема тестах, необхідно питання ставити так, щоб не порушувалися міжпредметні зв'язки, й учні отримували розуміння і могли пояснити в чому предмети доповнюють один одного і формують цілісну систему [1].

Змагальність відіграє важливу роль при визначенні змісту, методів організації навчально-виховного процесу, який має укладатися на основі органічного поєднання загальної і професійно-технічної освіти.

У підготовці кваліфікованих робітників особливе значення має узгодження теорії і практики. Яскравим виявом цього є зв'язок спецтехнології і виробничого навчання із застосуванням комплексних навчальних робіт. Завдання - навчити учнів виконувати роботи, характерні для їхньої професії, із використанням знань, одержаних з освітнього курсу «Інформатика та змагальні технології», застосування на уроках виробничого навчання ілюстративного матеріалу - як електронного, так і друкованого, давало б змогу передати учням значний обсяг відомостей, дозволяло б унаочнити процес 3 використанням записаних на файлі фрагментів елементів різних систем, вміння застосовувати імітаційні моделі кінематики і динаміки простих механізмів і систем керування, здійснити моделювання маршрутно-операційних технологічних процесів тощо.

Отже, розширювався і поглиблювався б політехнічний світогляд, формувалася обізнаність з науковими основами і організаційно-економічними принципами сучасного виробництва. Відповідно до програми виробничого навчання учні можуть готувати дидактичний матеріал для кабінетів i лабораторій, виконувати ескізи для оформлення методичних посібників та виготовляти інструменти, пресування, сувеніри, технічні іграшки моделей, механізмів, що їх можна реалізувати в процесі виробничої діяльності [6].

Висновки. Новітні IT у процесі викладання дозволятимуть краще подати учневі графічний матеріал для читання і виконання креслень, забезпечать можливість не лише самостійного розроблення технічної документації для виготовлення деталей і предметів, а і змогу розв'язувати творчі завдання 3 елементами конструювання, можливість самоконтролю в індивідуальному режимі, порівнюючи кожного разу кінцевий продукт, а за рахунок Інтернету дистанційно і з іншими учнями, що виконували це завдання. 


\section{Література}

1. Бодалев А. А. Некоторые вопросы комплексного подхода к совершенствованию системы подготовки учителя в педвузе / А. Бодалев; в кн.: О системах и системности в воспитании. - Ч. 2. - М., 1986. - 166 с.

2. Борлак О. Використання інформаційних технологій у підготовці висококваліфікованих робітників / О. Борлак, Т. Нерода // Професійно-технічна освіта. 2002. - № 3. - C. 21-23.

3. Інформаційні технології у професійній підготовці майбутніх вчителів трудового навчання:[ монографія] / О.М. Торубара. - Чернігів: ЧДПУ, 2009. - 304 с.

4. Інформаційне забезпечення вищої школи України / Володимир Луговий, Наталія Халікян // Вища освіта України. - 2007. - № 3. - С. 48-51.

5. Сидоренко В.К. Підвищення якості навчання учнів ПТНЗ засобами інформаційнокомунікаційних технологій / В. Сидоренко, Н. Тверезовська // Проблеми інженернопедагогічної освіти : [зб. наук. праць]. - Випуск 13. - Х. : УІПА. - 2006. - С. 12-21.

6. Сидоренко В.К. Умови забезпечення навчальної діяльності учнів профтехучилищ засобами інформаційних технологій / В.К. Сидоренко // Інформаційнотелекомунікаційні технології в сучасній освіті: досвід, проблеми, перспективи : [зб. наук. праць] - Львів: ЛДУ БЖД, 2006. - С. 86-91.

7. Торубара О.М. Використання засобів новітніх інформаційних технологій в системі розвитку творчих здібностей учнів / О.М. Торубара // Освітянські обрії: реалії та перспективи: [зб. наук. праць] / Н.Т. Тверезовська (голова) та ін. - К. : ІПТО, 2007. - №1 C. $429-431$.

Стаття надійшла до редакції 12.05.2012 p.

УДК 37.013 .42

Н. Л. Сеньовська,

кандидат пед. наук, асистент,

Тернопільський національний педагогічний університет

імені В. Гнатюка

\section{ГЕНДЕРНИЙ ПІДХІД У СЕРЕДНІЙ ОСВІТІ (НА МАТЕРІАЛІ ВИВЧЕННЯ ДРАМАТУРГІЇ ЛЕСІ УКРАЇНКИ В 10 КЛАСІ)}

Сеньовська Н. Л. Гендерний підхід у середній освіті (на матеріалі вивчення драматургії Лесі Украӥнки в 10 класі).

У статті охарактеризовано тендерний підхід у середній освіті, щзо полягає як у тиражуванні наявних тендерних стереотипів, так і в просуванні ідей тендерної рівності. Описано тендерний аналіз драматичних поем Лесі Українки як один із засобів корекції процесу сойіалізації молоді залежно від статі.

Ключові слова: тендер, тендерні стереотипи, тендерний підхід в освіті, гендерний аспект вивчення драматичних творів.

Сеневская Н.Л. Гендерный подход в среднем образовании (на материале изучения драматургии Леси Украинки в 10 классе).

В статье охарактеризирован гендерный подход в среднем образовании, который заключается как в тиражировании имеющихся гендерных стереотипов, так и в продвижении идей гендерного равенства. Описан гендерный анализ драматических поэм Леси Украинки как одно из средств коррекиии процесса сочиализащии юномества в зависимости от пола.

Ключевые слова: гендер, гендерные стереотипь, гендерный подход в образовании, гендерный аспект изучения драматических произведений.

Senevskaya N. Gender approach in secondary education (to study drama material Lesia Ukrainka in grade 10). 